\title{
Licensing Services Innovation Establishing Buildings in One Stop Integrated Services in North Jakarta
}

\author{
Lukman Hakim¹'Johanes Basuki², Triyuni Soemartono33, Kusworo4 \\ 1-4 Postdoctoral of Institut Pemerintahan Dalam Negeri \\ lukmanhakimipdn@gmail.com \\ ${ }^{*}$ Corresponding Author
}

How to Cite : Hakim, L., Basuki, J., Soemartono, T., Kusworo, K. (2019). Licensing Services Innovation Establishing Buildings in One Stop Integrated Services in North Jakarta. International Journal for Educational and Vocational Studies, 1 (7), 667-675

\section{ARTICLE HISTORY}

Received: 7 August 2019

Revised: 19 September 2019

Accepted: 20 October 2019

\section{KEYWORDS}

Innovation; Service Performance; Building License;

Local Government;

\begin{abstract}
This article aimed to determine and analyses the implementation of innovation forms as well as the factors supporting and inhibiting the implementation of innovation in local government level. The research was conducted in north Jakarta. The research conducted One-Stop Integrated Service Office. The results showed that the licensing office innovated to accelerate building permits, which was easy and inexpensive with describe establishing building procedures, then start a variety of innovations carried out by One-Stop Integrated Service Office one day, register IMB online, IMB 3.0, bleaching IMB. And this is an important requirement for the business world. In providing services to business operators, efforts are needed from the government to implement good services by applying transparent, participatory and accountable principles, so that the community as a group that is served will get good service. Supporting factors for service innovation in the three regions were regulation and commitment of the local governments while the inhibiting factors of innovation implementation were the limited fund and incompetent personnel in service duties.
\end{abstract}

This is an open access article under the CC-BY-SA license.

\section{INTRODUCTION}

The low quality of service so far has encouraged the government to immediately make improvements to the quality of public services, asking for those related to licensing that are imaged as convoluted, difficult to access services, managing highly complicated procedures, requiring no certainty of time, and increasing the transparency of service costs required.

The concept of innovation can be searched in contemporary State Administration levels around the world, i.e public choice that views public service delivery system as one of attention centres and a value to be maximized (Frederickson, 1984; Osborne and Gaebler, 1992; Berman, 1996; Brown et al., 2016). Therefore, organizational regulations can encourage innovation that can improve the performance of public services (Podger, 2015), and respond to citizen expectations and society needs (Mulgan and Albury, 2003), including leadership (Kim and Yoon, 2015; Munro, 2015; Siagian et al., 2019).

In addition, the communication and information technology-based service innovation is one of the tools used to actualize accountable and transparent services as a pillar of good governance (Ratminto and Winarsi 2005; Kim et al., 2005; Mukarromah et al., 2019). This can't be separated from the dynamics of public sector organizations that require innovation in the form of implementation of new technologies, new methods in order to improve the results and quality of service products including the increase in local revenue. In turn, the terminology of government service is: the delivery of services by a government agency using its own employees, so efforts to improve the quality of services will become increasingly important.

In Indonesia, innovations in administration of regional governments especially related to services began to receive attention since the enactment of Law No. 32 of 2003 on Regional Government. Furthermore, Law No. 25 of 2009 on Public Service and Regulation of the Minister of Administrative and Bureaucratic Reform No. 30 of 2014 on Guidelines for Public Service Innovation. Prasojo, Kurniawan and Hasan (2004) in their study suggest that regions that successfully implement innovation on licensing services can improve the quality of service, and satisfaction and welfare of community. 
Along with the development dynamics of the current IMB licensing service, researchers took the research area in the One Stop Integrated Service (PTSP) of North Jakarta City. It stands to reason that the location of North Jakarta is a gateway for national and international investment climate so that licensing issues must be better resolved. So PTSP North Jakarta becomes one of the main issues that will improve the business climate, encourage private investment, both domestic and foreign in addition to increasing the ease of public services.

However, some of these regulations cannot improve the investment climate in Indonesia, especially in the City of North Jakarta. Although the importance of online IMB has been socialized to several villages in the hope of facilitating licensing, legal protection, increasing the value of property sales and facilitating buying and selling and leasing transactions. But in reality, this rule is not enough to attract investors in, besides that it can also cause a setback from the goals of bureaucratic reform in improving the quality of public services through innovations carried out at the North Jakarta One Stop Integrated Service (PTSP).

Based on the demands and needs of public services above, the DKI Jakarta government has instructed all mayors to immediately implement public service innovations through the Government Regulation No. 38 of 2017 concerning Regional Innovation. Explicitly, regional innovation aims to improve the performance of government administration, especially in the City of North Jakarta. The implementation of public services in the form of goods and services in the City of North Jakarta is certainly the driving force of the national economy in the capital, ranging from national companies, foreign companies, banking centres, service and trade sector movers, to small and medium business activists.

\section{RESULTS AND DISCUSSION}

\subsection{Innovation for Success Good Government}

The ability of the government apparatus is one of the determining factors in achieving the goals of an organization. To carry out the duties and functions of North Jakarta City PTSP in IMB services.

Generally, PTSP requires adequate and competent apparatus (especially in mastering informatics and computers), because the activities of a work unit that is not supported by good apparatus resources are difficult to be able to achieve the stated organizational goals. Apparatus as an executing element in the activities of the organization has a very important role for the smooth running of the tasks of the office concerned in order to provide excellent service to the community. Apparatus that has a good quality of resources, very large influence on the success of achieving organizational goals, because after all the good planning and sophisticated facilities and infrastructure used is largely determined by the ability and quality of the apparatus resources.
The findings of the process of changing the level of innovation that reflect variations in the magnitude of the impact caused by ongoing innovation (This level of innovation level is explained by Evert M. Rongers (Yogi, 2008: 16-18 and in Muluk 2008:46) ranging from incremental, radical, to transformative or more so called (continuous innovation) which is an innovation process that brings new changes but by still basing themselves on the conditions of service and the system that is running or existing products)

The level of innovation in IMB services conducted by North Jakarta City PTSP tends to experience a slight change from conventional services provided. Where changes occur only to the extent of service procedures, and service time only, without multiplying changes to change the organizational structure.

The innovations given did not make a big change to the organizational structure, and only a small change to the procedures of service. Even though the changes that occur are small, the ball pick-up service can be done continuously, because it will provide many benefits to the community. The IMB service innovations made did not change the organizational structure and the changes that occurred were only minor changes, namely the service procedures and the location of services that were not only done in the North Jakarta City PTSP office.

Public acceptance and understanding of IMB information cannot be separated from the information media used to convey information about IMB and also the information content in the form of messages about IMB that are accurate, clear, complete and interesting so that people are more interested in listening to the existing messages to then understand and behave according to what is expected from the message received. Public acceptance and understanding can be seen from their knowledge, attitude and also how people behave towards IMB information after knowing it. Public acceptance of IMB information causes them to know what might not have been known before, then with their knowledge will lead to attitudes in the form of a tendency to behave in a certain manner towards IMB information that they already know.

The ease of observing the process of innovation, is one of the keywords to accelerate the improvement of public services. Efforts to accelerate the improvement of the quality of public services are not few. Some regional heads at the Regency level in Indonesia have successfully implemented innovations in various fields of public services. These best practices are then tried to be compiled by the Ministry of Administrative Reform and Bureaucratic Reform through the "One Agency, One Innovation" Movement to encourage the acceleration of public service improvement.

As you well know, transforms has a vision of being able to become a centre of study, supporting a network of policy makers, researchers and community representatives, in assessing public issues and finding solutions. The aim is to 
develop fact-based public policy making. It is only through this method that quality public policies can be produced, towards the welfare, equality and sustainability of resources in Indonesia.

Rogers' point of view (2008) innovation as an idea, practice or object/object that is realized and accepted as something new by a person or group to be adopted, IMB 3.0 Service is a revolutionary idea from the DKI Jakarta Regional Government and accepted as something new by the community. Because IMB 3.0 Service Innovation aims to improve IMB services that were previously completed in a long time and through various SKPDs and to achieve effectiveness and efficiency. With efforts to accelerate the completion of the IMB document, it encourages the people of DKI Jakarta who have an area of less than $200 \mathrm{~m} 2$ to make an IMB. Even with the free retribution, the public is very inclined to make a building permit.

When viewed from the typology of public sector innovation, IMB 3.0 Services conducted by North Jakarta City PTSP is included in the type of process innovation typology because this service refers to a combination of organizational changes, procedures and policies. However, the service did bring changes to interact with service users in terms of licensing to build buildings. However, this service does not bring overall changes in interacting with service users / the public. If there are obstacles that cause licensing obstruction, then there are normal procedures available at customer service. So that this type of typology is included in strategic or policy innovations that refer to the vision, mission, goals and strategies because this service is to simplify service procedures then become a reference for the North Jakarta Mayor Decree.

The government's program to improve public service innovation has been started since 2013. Many innovation programs that have been carried out have turned out to be not running optimally because they are only limited to innovation, but are not supported by the leadership to be included in the agency's permanent program. A qualified innovation should be included in the agency's program and budget because innovation is part of the tasks and functions of the agency and the innovation has a legal basis that eventually becomes the organizational culture. The existence of public service standards should have a strong benchmark with involvement of community participation and leadership commitment. So far, from our observations, IMB services that have a significant improvement effect cannot be separated from the leadership's commitment and even participate and be felt by the community. (Results of interview with PTSP Head of North Jakarta City on May 20, 2019 at 15:45:10)

The development and growth of the community which is dynamically accompanied by an increase in the standard of living and education of the community and coupled with the development of advances in the field of technology and informatics makes the process of empowering in the community environment increase. Therefore, bureaucratic services in the public sector are also expected to follow the changes that occur quickly and dynamically as happens in the community.

This condition can be realized only by realizing public services oriented to the ease of accessing licenses in the regions. Access to services for investors can be created if the state apparatus has a high spirit of dedication and professionalism in the delivery of public services. On the other hand, developments and changes caused by globalization that affect all aspects of life such as in the economic sector, investment, goods and services, make the bureaucratic actors (apparatus) increasingly challenged and demanded to improve the quality and quantity of services to the community. At this level, public service innovation in the region becomes an increasingly strategic issue because the improvement of the performance of the bureaucracy has broad implications in people's lives, especially in improving the level of investor community trust in local governments.

\subsection{Impact of service innovation on business and society}

Based on the results of studies in the field shows that the IMB service innovation in the North Jakarta City government, can be seen from the application of service dimensions in one of the government work units that has been providing services to the city community, namely integrated service organizational units, so that the needs of the community in big cities for excellent service and to be able to keep up with the increasingly dynamic development of urban society, causing changes in the process of public service. It is expected that with changes in the IMB 3.0 service process it can increase, with an increase in the regional income, programs that are community empowerment can increase so that the welfare of the community can also be increased. Changes in the service process, North Jakarta City PTSP as an agency that conducts investment licensing has implemented innovations in its services. Changes in investment services can be made with innovations in the service process felt to have implemented innovations in their services.

Licensing innovation received a good response from the building owner community because the innovation was considered to facilitate IMB licensing services that had previously had IMB licensing issues that had complex problems that caused the community's reluctance to arrange IMB. Based on several statements obtained from the informants, it can be seen that the response of the building owner community in managing the IMB shows support in a positive direction. This positive response was also supported by the presence of good knowledge and understanding from employees and the community building owners. The existence of a positive understanding and response then raises an attitude that shows a willingness and high commitment to always carry out functions and tasks with full compliance and responsibility in line with the directions and rules that have been determined. 
The impact of the IMB licensing service innovation received a response from the community or the building owner. This can be seen from the existence of a product that is used to overcome problems and provide facilities in the area of IMB licensing. The impact of innovation is an impact that follows a process of disseminating an innovation or renewal. Many people assume that the dissemination of innovation always has a positive impact, because as an innovator it is assumed that innovation is a people's need. Therefore, the dissemination of innovation is considered an appropriate action taken.

The IMB service innovation that was implemented in a one-stop integrated service in North Jakarta was said to have succeeded in increasing the response of building owners in North Jakarta. The impact of IMB 3.0 service innovation and community response can be proven from the existence of people who have no difficulty in taking care of IMB and increasing the response of community building owners in management, so that from year to year the number of people who take care of IMB is increasing. In addition, there are also changes to the level of management of the IMB by the community itself, although not many of them still ask for help in the management via telephone (WhatsApp). The direct impact received by the community and the government itself is also proof that the innovation in building permits in the North Jakarta One Stop Integrated Services Office has been quite successful and has become a comparative study for other provinces in Indonesia. The ease with which this innovation is provided has had a positive impact on society, namely the community's excellent response to licensing service innovation.

In general, the existence of Law Number 25 Year 2009 regarding Public Services is one of the important milestones in the protection and guarantee of the rights of citizens and citizens of Indonesia in obtaining good public services. The guarantee of the Public Service Act seems to be insufficient, the implementation of the Law No. 25/2009 on Public Services is becoming more important, where many people still do not get public services that are not in line with their expectations. The community acknowledged that there was an increase in public services, but the increase was not in line with their expectations.

Public service innovation is said to be a breakthrough initiative from public agencies / institutions in an effort to improve the quality of public services. The breakthrough initiative lies in novelty. The principle of novelty is distinguished from innovation in technology which is a uniquely different from the others. Novelty can be a development of existing public service innovations, because public service innovations are continually updated and even replicated by replicating. With the popular language, replication of public service innovation is carried out with an easy process, namely Observe, Imitate, and Modification or abbreviated.
The biggest contribution to North Jakarta's revenue came from the manufacturing sector, followed by the trade, hotel, restaurant and transportation and communication sectors. And last but not least, North Jakarta has a port that is the main node of export and import activities for all strategic commodities for the country such as warehousing, industrial zones with various factories, trade canters, and the busiest beach tourism. That is why the various North Jakarta infrastructures received serious attention from the central and regional governments because they were considered to be very important to drive the movement of the Jakarta and national economy.

The better economy in North Jakarta supported by various shopping centers to satisfy the level of public consumption. Construction of malls and shopping centers is very fast along with the growing economy and become a place of residence for entrepreneurs who run and control their business activities.

\subsection{Supporting factors innovation for Establish Building Licensing (IMB)}

The implementation of IMB service innovation in one-stop integrated services in North Jakarta has so far been running quite smoothly and can significantly increase the number of IMB owners in the North Jakarta area. The increase, of course, is directly proportional to the level of public awareness to have an IMB that is starting to improve. Therefore, it is important to be maintained so that future innovations will not stop and become more positive. To protect PTSP North Jakarta City needs to anticipate the factors that influence the implementation of innovation. By knowing some of these factors PTSP North Jakarta City can strengthen the supporting factors and anticipate things that can hamper the innovation of building permit services in the City of North Jakarta.

Factors that support the implementation of IMB innovation in the City of North Jakarta include:

a) Time and cost efficiency; IMB innovation carried out by North Jakarta City PTSP in the IMB 3.0 Service program and one day service has shortened the time of making IMB which was originally 14 working days. The speed of this service has a value of closeness with the level of user satisfaction IMB services. Because in general the fast service of IMB 3.0 has become an exclusive feature that can be obtained by issuing greater costs (the need for technological facilities and infrastructure). But on the IMB innovation in the city of North Jakarta, people can get fast service without the need to pay extra. Management fees have also been lower since the implementation of online-based services. This cost reduction is because each applicant only needs to submit the requirements at the initial and subsequent stages that have been stored in the PTSP database. Innovation is the creation and process, service products and new service methods that are the 
result of efficiency, effectiveness or quality of results. Especially with the IMB 3.0 program, one day service, pick up the ball which overall makes the process of making IMB more efficient, because the community only needs to go to the IMB service point both in district and sub-district, thus the community can greatly save time and costs, especially can IMB can be completed in just one day. However, this one-day service program only applies to the IMB bleaching program only with the required conditions complete and can be directly processed.

b) Cooperation and coordination between employees; Cooperation and coordination between employees, both leaders and subordinates, between employees in an organization is very necessary in achieving the goals of the organization. Likewise, in providing services to the community, officials should cooperate with each other in carrying out their duties. In order to make the services provided to the public easier, faster, and more appropriate, collaboration between employees is the main key. Because one employee with another employee needs each other. For example, employees who are hired don't have the possibility to type letters. Because of that, their duties have been distributed so that the services provided to the community are more effective. In North Jakarta City PTSP, according to the author's observation, it is indeed applying the system of distribution of authority, not the separation of authority. The point is that one apparatus is cooperating with one another in completing a task, without depending on their respective fields of work or example cases, for example, if an officer is unable to attend, then the other officials are willing to replace him so that the service is not delayed. This system is indeed suitable for use, because the authorities assigned to service based on facts in the field are not yet professional between the workload and the number of officers.

c) Legal basis; Implementation of Building Permit (IMB) in the Government of DKI Jakarta, specifically North Jakarta City and its relationship with the IMB implementation process is regulated in DKI Jakarta Governor Regulation No. 28 of 2016 concerning Building Permit and DKI Regional Regulation No. 1 of 2015 concerning Regional Retribution. The aforementioned local regulation is the formal legality that underlies the implementation of building permit services, so that it is binding on the community. This legal basis also provides capacity for implementing agencies to carry out their duties and functions in accordance with the given field. Therefore, constitutionally with the existence of these regulations is very supportive in the implementation of services to the community, because it will provide clear directions and targets in realizing good service quality.

d) Trainings for employees; Training for apparatus is needed in supporting and enhancing the skills and abilities of officials as servants of the state and servants of the community, therefore this is one of the supporting factors for the creation of better services and for expanding the knowledge of the apparatus to respond to challenges in serving the public increasingly diverse. In order to provide more effective services to the community, the skills of the employees are needed. Therefore, North Jakarta City PTSP conducts training for each employee so that in the future there will be no more problems in answering questions from the community because they have been trained.

e) Socialization; IMB socialization is an activity to introduce rules and programs to the public so that they can understand it. This socialization activity is the right step to provide clear information to the public about the function and role and importance of the IMB when building residential buildings or other types of buildings. The socialization activity is a step taken by the city government through PTSP of North Jakarta City to provide clear information to the community that has been regulated in DKI Jakarta Governor Regulation No. 28/2016 concerning Building Permit and DKI Regional Regulation No. 1/2015 concerning Regional Retribution, concerning building border lines, fence border lines, building construction, IMB maintenance procedure mechanisms and sanctions that will be given if they violate the provisions given. Routine socialization activities are carried out twice a year, namely in February and November, and involve relevant elements such as the City Planning Office, sub-districts and community leaders. In an effort to control the use of space. The socialization about IMB is a normative reference that is binding on the construction of a building, if it is not understood by the community then naturally the community is less concerned about the importance of the IMB. In connection with the foregoing, there is a need for socialization activities regarding IMB and all forms of legislation relating to IMB itself so that the public can understand well the mechanisms and procedures as well as the requirements needed to administer the IMB as well as sanctions against violations of applicable provisions.

f) Timeliness of Service; The one-day IMB program is one of the programs created to improve the quality of IMB Bleaching services and attract the interest of the community to immediately make IMB. In its implementation this program can be realized on time in accordance with its name. However, this accuracy can be achieved with the notes, application files and required requirements can be directly processed and not problematic. This can affect the timeliness of the program. For this reason, it is expected that the public who wants to make an IMB must re-check the completeness of the documents and requirements so that the IMB can be completed within one day.

g) Ease of Management; Also, through innovation, the community is increasingly facilitated by a number of 
changes to the requirements for making IMB. For IMB Bleaching, the requirements specified are very flexible and make it easier for the applicant. Such as building sketches that are required do not require special software but only hand drawings. The applicant can also ask the ticket window clerk if they have difficulty in drawing. This innovation greatly facilitates the public rather than having to incur additional costs for hiring illustrator services when using software. Then, another convenience in making IMB in North Jakarta is to have implemented an online system. So that the process of registration, checking rates, and checking files can be done without having to come to the North Jakarta City PTSP. With these innovations, people can save time and transportation costs to take care of IMB.

h) Smooth management; Smoothness in the management of IMB in the City of North Jakarta, there is the involvement of personnel in making decisions regarding their respective fields of work which has been delegated to sub-sections and fields. At this level, if there are problems that arise relating to the task of a sub-section, then all personnel in the sub-section are involved to take steps to solve them. On the other hand, if there is a problem that concerns the organization as a whole, then all fields are involved in solving the problem. The work implementation is based on a fixed procedure (Protap) in DPMTSP DKI Jakarta, based on the organizational structure and work procedures as well as other provisions relating to IMB ownership. The permanent procedure (Protap) is carried out with the intention that each granting of IMB to the public truly has an element of accuracy. All work related to IMB in a one-stop integrated service office (PTSP) is carried out with consideration to avoid unwanted deviations from service rigidity.

\subsection{Obstacle factor innovation for Establish Building Licensing (IMB).}

After knowing the supporting factors, it is also necessary to know the inhibiting factors in their implementation. Based on research by the author, found several factors inhibiting IMB services to the community include:

1) Lack of sub-district facilities and infrastructure; Facilities and infrastructure is one of the supporting factors that are very influential in the context of efforts to improve services to the community. The capabilities possessed by the apparatus cannot be utilized to the maximum extent possible if the facilities and infrastructure are lacking. This is what will adversely affect the performance of the authorities in carrying out their duties. In providing services to the community all employees have worked hard so that the services we provide to the community can be better, but that is not enough because there are still complaints from the community about the services we provide, especially in the case of facilities at the village level. When the community is in the waiting room, they still feel the heat because there is no AC provided besides the information room is not functioning properly.

2) Service; Because currently the IMB permit in the North Jakarta City has been based online, it automatically requires a stable network condition to support the process of making IMB. Even starting from the registration process to checking the permit status, the online system has been implemented. This is of course a very positive progress in the licensing of IMB in the City of North Jakarta. But online implementation cannot be ensured to always run smoothly. There are times when the server experiences interruption (2-3 days) which causes the internet connection is lost. If this happens often, of course, it will hamper the ongoing process of making IMB.

3) Human Resources (HR); IMB process is a permit that regulates how a building should stand from the technical side as well as administration according to the Building Regulation. To do this, we need workers who have knowledge in building techniques. The team created to carry out ball pick innovation should also have similar competencies. But with the concentration of tasks as above there is a tendency that the implementation of IMB innovation will depend on the team in charge. If this happens when there is one of the team who is unable to make the IMB process will not run optimally. Of course, this will again result in public dissatisfaction.

4) Not yet the maximum means to support innovation; IMB Bleaching using ball pick-up and daily methods requires facilities and infrastructure that support its implementation. In this case, North Jakarta City PTSP has formed a team that is tasked at the points where the IMB owner is still lacking. The formation of this team is supported by operational support facilities as long as they provide IMB services to get the ball. But for now, the facilities and infrastructure that there are only one operational car and a set of computers to make the IMB. One device is still considered lacking because it is only able to reach one point in one day. Not to mention if there is a problem with the car or computer, the ball pick-up service cannot be done.

5) Limited Implementing Apparatus; North Jakarta City PTSP employees, namely as the executor of the IMB service task, are not professional enough in quantity. The number of available employees does not match the existing workload. Where North Jakarta PTSP is still lacking in number of employees, even though providing a good service to the community does require more workers. Furthermore, so that the work being done can be completed on time, so that the community will also feel more satisfied with the services provided.

6) Operational Funds; As with the factors outlined above, the operational funding factor is also very 
influential on the achievement of the objectives of IMB service implementation. From the findings on the ground that operational funds in the implementation of the IMB service delivery tasks, especially in North Jakarta City PTSPs are insufficient. This can be seen in the lack of facilities and infrastructure, especially at the Sub-district level, employee welfare which is still considered low such as financing for BBM, as well as stagnant routine activities such as field inspections and site supervision due to budget constraints. During the working day, there are actually a lot of tasks that must be done by employees, one of which is a visit to the location where the building was built by the community. But it was all hampered because of the lack of operational costs contained in the North Jakarta City PTSP. With these constraints, the employee cannot complete the task on time, this will also affect the service to the community. That way maybe the community's view will be negative towards the services that will be provided. For this reason, the operational funds in question need to receive the main attention of the government in the context of relocating funds for regional development activities.

7) Lack of Community Financing Readiness; Administrative costs are an obstacle experienced by people who do not have money and small income. In accordance with the reality in the previous discussion that indeed in North Jakarta PTSP there are still some communities that have built but do not yet have an IMB, this is due to their inability to pay IMB fees and the average level of their income.

Some of the indicators above can provide a general description of the state apparatus capabilities in DKI Jakarta, especially in North Jakarta City PTSP in terms of IMB services, but when viewed in terms of the quantity of officers in charge are still not professional according to the research conducted by the authors who do the employees at PTSP The city of North Jakarta numbered 11 people, so if it is calculated it must be in one office to have a minimum of 15 implementing staff (not including the section head and division head). The policy to cover this shortfall has been pursued by North Jakarta City PTSP by recruiting three honorary staff, who are seconded in the administration and licensing department, but even that hasn't been able to answer the problem.

The obstacle for the government apparatus in providing IMB services effectively in North Jakarta City PTSP is regarding facilities and infrastructure. The conclusions that can be drawn from the results of the study concerning the facilities and infrastructure at PTSP North Jakarta are not yet optimal, especially the use of computers, file cabinets, and operational vehicles. Besides that, the office atmosphere is not conducive (especially at the sub-district level) and feels cramped when compared to the workload and number of employees on duty, things like this naturally cause a sense of community dissatisfaction in the management of IMB.

For the supporting factor of the ability of the government apparatus in providing services in North Jakarta City PTSP is also quite good, this can be seen from the cooperation carried out by the government apparatus both between leaders and subordinates as well as between fellow employees. This collaboration is very necessary in achieving the objectives of an organization, especially in North Jakarta City PTSP in providing IMB services. In North Jakarta City PTSP, according to the author's observation, it is indeed applying the system of distribution of authority, not the separation of authority. The point is that one apparatus with another cooperates in completing a task without depending on other fields. In this study the authors found a few other obstacles for North Jakarta City PTSP employees in providing services effectively to the community, especially in the provision of this IMB in addition to facilities and infrastructure, namely, regarding operational funds in carrying out tasks is still insufficient, employee welfare is still low, and the existence of routine activities that have faltered due to the lack of operational funds.

Based on the analysis of the model above, in public service there is a policy by the organizer of the public interest to meet the public interest which has an element of novelty and usefulness. These criteria include; financial value, moral value, social value, political value, cultural value, aesthetic value. At the empirical level, the benefits of innovation can be identified in several manifestations, including: acceleration of work processes or procedures, increasing effectiveness and efficiency in the use of resources, integrating several types of services into an integrated, expanding public choice of goods public goods, strengthening public engagement in decision making or public policy, reducing the burden of society on government services, as well as other benefit models that continue to evolve according to the dynamics of the needs of public organizations and stakeholders.

Empirically, policy innovation based on process places more emphasis on the quality of work processes both external and internal to make it simpler and more efficient. The following are examples of the application of policy innovation products the empirical facts of innovation methods are more aimed at implementing a new way, strategy and technique to achieve better results. Technology-based policy innovations are aimed at the creation or use of new technologies that are more effective and able to solve problems incrementally. This incremental innovation model generally follows the directions suggested by technology experts and innovates based on technological capabilities. Utilize sustainable investment in research and development institutions to drive innovation breakthroughs and incremental change. Where incremental innovation is the process of adjusting and implementing small-scale improvements. The ones who carry out this innovation are all parties concerned so that the empowerment approach is in accordance with this incremental innovation model. This innovation suits 
not only experts but all employees involved in the innovation process. Therefore, the employee empowerment system is very much needed in this innovative model.

Innovation is not completely new, both in terms of physical features and features that complement it. Innovation can occur because of a process known as re-invention. This process is not the process of rediscovering original innovation, but rather is pseudo-innovation. This process is often carried out for the purpose of bringing innovation closer to the user. Often the innovations that appear are very strange to potential users. In a public service, the investment process is also possible, with the intention that the younger public service will be accepted by the local community. The meaning is that public services are essentially the same, but local content must be a concern, especially with the diverse conditions of ethnicity, religion and local culture in each region.

\section{CONCLUSION}

The success of innovation is measured by the extent to which public policy performance is able to be the best solution for the community. The synergy between conceptual and empirical level is a continuum in the effort to reconstruct sustainable public policy innovations. The structure, culture, technology and leadership framework can offer interesting concepts and need to be considered in building commitment and awareness of public policy innovation. On the other hand, the process, dynamics and practice of innovation must be adaptive and replicative, this is important because of the diversity of problems and characteristics of organizations and society

In the end, the innovation model in the public sector will only succeed if many people have the ability to reach it. This model becomes meaningless, and makes no difference if it cannot be widely used by the public. This innovation also pays attention to local culture and identity as part of the process of adapting a better innovation model. The use of local identity is not only strategic in bringing innovation closer to its users, but also part of an appreciation of the existing culture. This cannot be separated from the character of the new innovation which tends to shift the old values and culture.

\section{REFERENCES}

Ansari, Muhammad Insa. (2016). Inovasi Pelayanan Terpadu Satu Pintu Perizinan Usaha di Aceh Besar dan Aceh Barat Daya. Kaunam: Jurnal Ilmu Hukum. Vol. 18, No. 1, (April, 2016), pp. 17-35. Diunduh pada Tanggal 28-04-2019, 16:00 Url: http://www.jurnal.unsyiah.ac.id/kanun/article/downl oad/5915/4869.

Avianto, BN. (2018). Analisis Indeks Kepuasan Pelayanan Administratif Disdukcapil Kabupaten Brebes dalam Presfektif Loyalitas Publik. Jurnal
Syntax Literate, Vol: 3 (07) 25-44. http://scholar.google.co.id/citations?user=UY0x7FsA AAAJ\&hl=id. Access 28:072019 Time: 03:42:13 GMT

Basuki, J. (2012). Budaya Pelayanan Publik. Suatu Telaah Teoritis. Jakarta: Hartomo Media Pustaka.

Batinggi, A dan Badu A. (2013) Manajemen Pelayanan Publik. Yogyakarta: Andi Offset.

Christensen \& Lægreid. (2006). The Whole-of-Government Approach - Regulation, Performance, and Public-Sector Reform. Working Paper.

Dwiyanto, Agus. (2008). Mewujudkan Good Governance Melalui Pelayanan Publik. Yogyakarta: Gajah Mada University Press.

Junior, Marten Prasetyo. (2016). Inovasi Pelayanan Publik (Studi Kasus Perizinan Penanaman Modal di BPPT Kota Semarang). E-Jurnal Undip. Diakses pada Tanggal 8 Agustus 2018 Jam 09:00:10 https://webcache.googleusercontent.com/search?q=ca che:D9YNdvBx5XsJ:https://media.neliti.com/media/ publications/108594-ID-inovasi-pelayanan-publik-st udi-kasus-per.pdf $+\& c d=2 \& h l=i d \& c t=c \operatorname{lnk} \& g l=i d$

Kurniawan, Ahmad Dwiky. (2015). Inovasi Pelayanan Publik. Studi Deskriptif tentang Inovasi Pelayanan Surat Izin Usaha Perdagangan (SIUP) di Badan Penanaman Modal dan Perizinan Kabupaten Lamongan. Jurnal: Kebijakan dan Manajemen Publik. ISSN 2303 - 341X. Volume 3, Nomor 3, September - Desember 2015. Diunduh Tanggal 28-04-2019 Jam 10:00 pada Url: http://journal.unair.ac.id/download-fullpapers-kmp0 a6972c05ffull.pdf

Ling, Tom. (2002). Delivering Joined-up Government in the UK: Dimensions, Issues and Problems. Public Administration. Vol 80:4, 615-642.

Lukman, Sampara, (2000). Manajemen Kualitas Pelayanan, Jakarta : STIA LAN Press

Mardiasmo. (2009). Otonomi dan Manajemen Keuangan Daerah. Andika Press. Yogyakarta.

Mutiarin, Dyah dan Zaenudin, Arif. (2014). Manajemen Birokrasi dan Kebijakan. Yogyakarta: Pustaka Pelajar.

Miles, B. Matthew dan Huberman, A. Michael. (2014). Analisis Data Kualitatif: Buku Sumber Tentang Metode-Metode Baru. Jakarta: UI Press.

Moleong, Lexy J. (2009). Metodologi Penelitian Kualitatif. Remaja Rosda Karya. Bandung.

Mukarromah, I., Mudjito, M., \& Purbaningrum, E. (2019). The Effect of Managerial Skills (Conceptual, Human, and Technical) of Headmasters to the Effectiveness of Islamic Senior High Schools in Jombang District. International Journal for Educational and Vocational Studies, 1(6).

Noor, Irwan. (2019). Desain Inovasi Pemerintahan Daerah. Malang: UB Press. ISBN: 
978-602-203-503-9

Ndraha, Taliziduhu. (2003). Kybernologi (Ilmu Pemerintahan Baru). Jilid 1-2. Rineka Cipta. Jakarta

Osborne, David dan Ted Gaebler. (2000). Mewirausahakan Birokrasi. PT. Pustaka Binaman Pressindo. Jakarta

Prasojo, Eko. (2008). Strategi Reformasi Birokrasi. http://news.okezone.com/read/2009 diunduh pada 21 Desember 2017 Jam 20:15

Rogers, Everest M. (2003). Diffusion on Innovations. Mac_Millian Publisher: New York.

Rockman, Bert A. (2002). Bureaucracy, Power, Policy and The State, dalam Lary B. Hill (ed), The State of Public Bureaucracy. M.E. Sharpe Inc. London.

Siagian, F., \& Sirait, J. E. (2019). The Influence of Director Leadership on Improvement of Creativeness Education Manpower, Productivity of Employee Education and Learning Success Students in Cirebon Maritime Academy. International Journal for Educational and Vocational Studies, 1(6), 533-538.

Tuti, Retnowati WD, Mufidayati, Kurniasih dan Mawar. (2016). Inovasi Pelayanan di Dinas Penanaman Modal dan Pelayanan Terpadu Satu Pintu Provinsi DKI Jakarta. Jurnal Kebijakan dan Manajemen Publik, ISSN 2303 - 341X Volume 4, Nomor 3, September - Desember 2016. Diunduh pada Tanggal 28-4-2019.

Url: http://asosiasipascaptm.or.id/images/phocadownload/ Jilid-2-OK-PRINT-ilovepdf-compressed-133-143.pdf

Warella. (2013). Mengukur Kepuasan Pelanggan. Jakarta: Padya Paramita.

Widodo, Joko. (2001). Good Governance: Telaah dari Dimensi: Akuntabilitas dan Kontrol Birokrasi pada Era Desentralisasi dan Otonomi Daerah. Insan Cedekia. Surabaya.

Yohanitas, Witra Apdhi. (2016). Menciptakan Good Governance melalui Inovasi Pelayanan Publik di Kota Surakarta. Jurnal: Jurnal Borneo Administrator/Volume 12/No. 3/2016. 18 Juli 2018 Jam 14:30 https://media.neliti.com/media/publications/52274-I D-menciptakan-good-governance-melalui-inov.pdf

Undang Undang Nomor 25 tahun 2009 Tentang Pelayanan Publik

Undang Undang Ombudsman Nomor 44 Tahun 2000

Peraturan Pemerintah Nomor 96 Tahun 2012 tentang Pelaksanaan Undang Undang Nomor 25 Tahun 2009 tentang Pelayanan Publik.

Permendagri Nomor 24 tahun 2006 Tentang Pelayanan Terpadu Satu Pintu (PTSP).

Permenpan-RB Nomor 30 Tahun 2014 tentang Inovasi Pelayanan Publik

Peraturan Provinsi DKI Jakarta Nomor 12 tahun 2013 tentang Penyelenggaraan Pelayanan Terpadu Satu Pintu (PTSP)

Peraturan Gubernur DKI Jakarta Nomor 47 Tahun 2017 tentang Peraturan Pelaksanaan Nomor 12 tahun 2013 tentang Penyelenggaraan Pelayanan Terpadu Satu Pintu (PTSP). 